\title{
STORTHYNGURELLA, NEW GENUS OF MUNNOPSIDAE (CRUSTACEA: ISOPODA), WITH DESCRIPTIONS OF THREE NEW SPECIES FROM DEEP-SEA BASINS OF THE SOUTHERN HEMISPHERE
}

\author{
M. V. MaLyUtina \\ Institute of Marine Biology, Far Eastern Branch, Russian Academy of Sciences, 17 Palchevsky St, \\ Vladivostok 69004I, Russia \\ (inmarbio@mali.primorye.ru)
}

\begin{abstract}
Malyutina, M.V., 1999. Storthyngurella, new genus of Munnopsidae (Crustacea: Isopoda), with descriptions of three new species from deep-sea basins of the Southern Hemisphere. Memoirs of Museum Victoria 57: 267-285.

A new genus Storthyngurella and three new species are described from deep-sea basins and trenches of the Southern Hemisphere. Storthyngurella is characterised by: long dorsal and lateral spines on the body; a terminal spine on the pleotelson; a long spine on the basal article of both antennae; narrow posterior pereopods 5-7; elongated distal lobes of male pleopod 1 extending far beyond the distal margins of pleopods 2; a long stylet of male pleopod 2, which is more than two-thirds as long as the protopod; and elongated uropods with tubular protopod and rami. The new genus is most similar to Storthyngura and Microprotus.
\end{abstract}

\section{Introduction}

A specialised deep-sea family Munnopsidae Sars, 1869 is characterised by natatory posterior legs with paddle-like carpi and propodi bearing plumose setae, fused compact natasome and streamline body outline. A small group of munnopsid genera is distingushed by spinose body, fused but non-compact natasome, and relatively narrow pereopods $5-7$, which in some cases are lacking natatory setae. This group comprises Acanthocope Beddard, 1885, Storthyngura Vanhöffen, 1914, and Microprotus Richardson, 1910. The most numerous (more than 40 species) and widespread genus Storthyngura shows variable external morphology. Its species are distinguished by different number and length of body spines, shape of pleotelson, and morphology of appendages. Among the representatives of the genus large active swimmers, which swim backwards, are characterised by relatively compact muscular body, paddle-like pereopods $5-7$, and short body processes directed forward; also a few elegant, brittle species have thin, long spines and narrow, often walking posterior legs. George and Menzies (1968a) tried to divide the genus into five groups and 14 subgroups. Although they wrote that their analysis was based on 158 characters, description of these subdivisions was based mainly on pleotelson morphology. Nevertheless, the groups were distinguished by other morphological characters such as armament of the antennae, morphology of the posterior pairs of pereopods and male pleopods. The artificiality of such a classification was noted by subsequent authors (Birstein, 1969; Wilson et al., 1989). Working with Storthyngura specimens collected by RV Akademik Kurchatov (cruises 11 and 43) and RV Dmitrii Mendeleev (cruises 16 and 43) from deep-sea trenches and basins of the Southern Hemisphere, I was able to compare 12 species of this genus. The new genus Storthyngurella is erected for three new species described in this paper and five previously known species of Storthyngura.

I am indebted to colleagues from the Laboratory of Benthos in Shirshov's Institute of Oceanology, Moscow, for the privilege of being able to examine the Storthyngura collections. The terminology and measurements follow Wilson and Hessler (1980). When measuring the body proportions the body spines were omitted. The type material is deposited in the Zoological Museum of Moscow University, Moscow, Russia (ZMMU) and Museum Victoria, Melbourne, Australia (NMV) . 
Suborder Asellota

Munnopsidae Sars, 1869

Storthyngurella, gen. nov.

Type species. Storthyngurella hirsuta sp, nov.

Diagnosis. Body slender, with long spines: dorsal on cephalon, pereonites and pleotelson, lateral on coxae of pereopods $1-4$, pereonites $4-7$ and pleotelson, and terminal on pleotelson. Posterior body part (natasome) longer than anterior part, noncompact, with distinct waist (narrowed anterior part of pereonite 5), pleotelson longer than broad, with long preanal ventral process. Antenna 1 sexually dimorphic: in males 1.5-2 times as long as in females, basal article of antenna 1 with long medial spine, basal article of antenna 2 with long lateral spine. Mandible normal, with cuticular posterolateral projection articulated with cephalon in elongate notch, proximal portion of mandibular body up to condyle and palp abbreviated. Pereopods 5-7 thin, either with tubular carpus and propodus lacking natatory setae or with flattened articles provided with short plumose setae, either on dorsal margin or in both. Dactyli of pereopods 2-7 with acute dorsal claw provided with inner acute projection. Male pleopod 1 elongated without distinct waist midlength, with long distal lobes making angle to each other and extending in situ far beyond distal margins of pleopods 2. Male pleopod 2 endopod inserted in midlength of protopod medial margins, stylet length more than two-thirds of protopod length, exopod with long distal hook. Pleopod 3 endopod with $3-4$, exopod with numerous plumose setae. Uropod elongate, with tubular protopod and rami subequal in length.

Additional description. Body widest at pereonite 4 , long dorsal and lateral spines directed perpendicularly to body axis and (or) backward (only in $S$. digitata body spines are short and of unusual bulbous shape). Cephalon without rostrum, broader than long, with pair ( 2 pairs in $S$. digitata) of long dorsal spines, laterally projecting cheeks at mandibular articulation point; frons sloping with frontal arch semicircular in frontal veiw. clypeus significantly broader than labrum. Pereonites 1-4 slightly broadening and lengthening from 1 to 4 , pereonites 2-4 with 3 dorsal spines (in $S$. wolffi sp.nov. and $S$. benti only with 1 spine), anterolateral margins of pereonites 1-3 rounded, of pereonite 4 with long spines, coxae of pereopod 1 with 1 , of pereopods $2-4$ with 2 long spines. Pereonites $5-7$ and pleotelson fused, dorsal sutures visible, ventral sutures absent, each pereonite bearing pair of dorsal spines located relatively far from each other and anterolateral long spines with narrow basis. Pleotelson with several (1-6) dorsal and 3 lateral spines (2 spines and a process between them in $S$. wolffi sp. nov. and $S$. digitata) directed backward. Basal article of antenna 1 same (equal) in both sexes, elongated, with subparallel margins, flattened lateral lobe and medial spine, exeeding in length article width, article 2 length 0.3 article 1 length and subequal in length to article 5 , article 3 slightly longer than article 2 , article 4 shortest among first five, in males articles $2-5$ broader and stronger than in females, flagellar articles in male short, numerous, in female flagellar articles less numerous, longer, subequal in length to article 4. Basal article of antenna 2 with long lateral spine, article 2 without spines, article 3 with 2-3 spines. Mandibular incisor process broad, flattened and more or less curved, condyle shorter than molar process, which narrowed distally, with row of small denticles and setae on tip, palp normal, long, thin, last article twisted. Maxilla I inner lobe with numerous small, thin distal setae, distomedial seta largest. Maxilla 2 lobes subequal in length, middle and outer lobes with 4 long spinelike distal setae, inner lobe bears thin simple marginal setae, distal setae more strong, some pectinated. Maxillipedal palp inserting in midlength of basis, palp article 3 with semicircular medial margin, epipod elongated, lateral margin smoth, lacking acuted rolling process. Pereopod I much smaller than posterior pereopods, having only simple setae, carpus slightly curved, dactylar dorsal claw finger-like, rounded distally. Pereopods $2-4$ progressively lengthening; straight carpi and propodi, bearing strong, unequal bifid ventral setae and sparse simple thin dorsal setae. All bases subequal in length. Male pleopods 2 not connected to each other, fully separated by insertion of pleopods 1; pleopod 2 protopod semicircular, lateral and distal margins with plumose setae. Female pleopod 2 (operculum) oval, with plumose marginal setae, median keel low, with or without spine.

Species included. All species except the new ones were transfered from the genus Storthyngura (Table 1).

Geographic distribution. Species of the genus Storthyngurella have been found mainly in the Southern Hemisphere: from Middle American Trench, $12^{\circ} \mathrm{N}$ to $61^{\circ} \mathrm{S}$ in the Atlantic and in the southeastern Indian Ocean in the depths of 2596 to $7200 \mathrm{~m}$. 
Table 1. List of species of Storthyngurella gen. nov.

Species Locality: (A), Atlantic, (I), Indian, (P), Pacific Oceans

Depths (m)

\section{S. hirsuta sp. nov.}

S. wolffi sp. nov.

S. menziesi sp. nov.

(A) South Sandwich Trench: $56^{\circ} 07^{\prime}-56^{\circ} 52^{\prime} \mathrm{S}, 24^{\circ} 56^{\prime}-24^{\circ} 59^{\prime} \mathrm{W}$

(I) South Australian Basin: $43^{\circ} 36.5^{\circ} \mathrm{S}, 144^{\circ} 04^{\prime} \mathrm{E}$

(P) Hjort Trench: $57^{\circ} 17^{\prime} \mathrm{S}, 157^{\circ} 13^{\prime} \mathrm{E}$

S. benti (Wolff, 1956)

S. spinosa

(Beddard, 1885)

S. triplispinosa

(George and

Menzies, 1962)

S. digitata

(Menzies, 1962)

S. zenkevitchi

(Birstein, 1969)
(A) Argentine Basin: $38^{\circ} 40^{\prime} \mathrm{S}, 48^{\circ} 08^{\prime} \mathrm{W} ; 48^{\circ} 52^{\prime} \mathrm{S}, 26^{\circ} 36^{\prime} \mathrm{W}$

(P) Kermadec Trench: $32^{\circ} 10^{\prime}-36^{\circ} 07^{\prime} \mathrm{S}, 175^{\circ} 54^{\prime}-178^{\circ} 32^{\prime} \mathrm{W}$

(I) South Indian Basin: $54^{\circ} \mathrm{S}, 109^{\circ} \mathrm{E}$

(P) Panama Basin: $16^{\circ} 12^{\prime} \mathrm{S}, 74^{\circ} 41^{\prime} \mathrm{W}$

(P) Middle American Trench: $12^{\circ} 11^{\prime} \mathrm{N}, 89^{\circ} 34^{\prime} \mathrm{W}$

(A) Argentine Basin: $44^{\circ} 53.3^{\prime} \mathrm{S}, 51^{\circ} 26.5^{\prime} \mathrm{W}$

$36^{\circ} 12^{\prime}-38^{\circ} 40^{\prime} \mathrm{S}, 48^{\circ} 08^{\prime}-49^{\circ} 10^{\prime} \mathrm{W}$

(A) Romanche Gap: $01^{\circ} 01^{\prime} \mathrm{S}, 18^{\circ} 21.55^{\prime} \mathrm{E}$
(A) $45^{\circ} 34^{\prime} \mathrm{S}, 06^{\circ} 02^{\prime} \mathrm{W}$
$5530-6150$

4464

4590

$5460-5760$

5225

$4560-4570$

$5340-7000$

3567

$2856-2596$

$5680-5690$

4588

5843

$4630-5255$

7200
Etymology. Representatives of the new genus are similar to but smaller and more elegant than species of Storthyngura. The diminutive suffix -ella is added to Storthyngura.

Remarks. Storthyngurella gen. nov. has clear affinities with the genera Storthyngura and Microprotus. From Storthyngura, the new genus differs in smaller body size, longer body spines and their arrangement, terminal spine of pleotelson, long spines on the first articles of both antennae, narrow pereopods 5-7, long distal lobes of male pleopods 1 which make an angle to each other and extent far beyond the distal margins of pleopods 2, and longer stylet of pleopods 2 , inserting at the midlength of the protopod.

Until now the presence of tubular pereopods 5-7 in Munnopsidae was described only for Microprotus. At least two species of Storthyngurella, S. menziesi and $S$. triplispinosa, have such legs, while other Storthyngurella species have carpi and propodi of pereopods 5-7 significantly narrower than in all munnopsids except Microprotus. Plumose setae in Storthyngurella species show different stages of reduction: either short plumose setae located on both margins of narrow carpi and propodi, or carpi and propodi bearing small plumose setae on dorsal margins and unequal bifid setae on ventral margins, or the plumose setae totally reduced. Wilson et al. (1989) discussed the hypothesis that there is secondary reversion of natatory legs into walking ones within this specialised swimming family. An intermediate stage of such a transformation is seen in Storthyngurella. Besides the narrow legs, long spines of the body, pair long spines on the coxae of pereopods $1-4$, long spine on the article 1 and article 3 of antenna 2 and long tubular uropods also make the new genus similar to Microprotus,

In spite of external similarity between Storthyngurella gen. nov. and Acanthocope (both have a long terminal spine on pleotelson, body spines, long uropods and narrow pereopods 5-7) a more detailed analysis did not confirm their close affinity. The monotypic subfamily Acanthocopinae is well isolated from other spiny munnopsid genera, first by the different structure of male genital apparatus (Malyutina, in press). Therefore, Wägele's (1989) unification of Acanthocope, Storthyngura and Microprotus into Acanthocopinae is dubious.

\section{Storthyngurella hirsuta sp. nov.}

Figures 1-3

Material examined. Holotype. South-Sandwich Trench, RV Akademik Kurchatov, cruise $11, \sin 898\left(56^{\circ} 47^{\prime} \mathrm{S}\right.$, 24.56 W), 6052-6150 m, ZMMU Mc 1316 (male, 11.1 $\mathrm{mm}$ long).

Paratypes. Type locality, ZMMU Mc 1317a ( 8 males, 7.4-12.3 mm long; 6 females, 9.3-11.7 mm long; 14 fragmented specimens), NMV J45733 ( 1 male, 1 female). Stn $896\left(56^{\circ} 52^{\prime}\right.$ S, $\left.24^{\circ} 9^{\prime} \mathrm{W}\right), 5530-5651 \mathrm{~m}$, ZMMU Mc $1317 \mathrm{~b}$ (5 males, 12 females, $6.5-13.4 \mathrm{~mm}$ long; fragments of 6 specimens). 


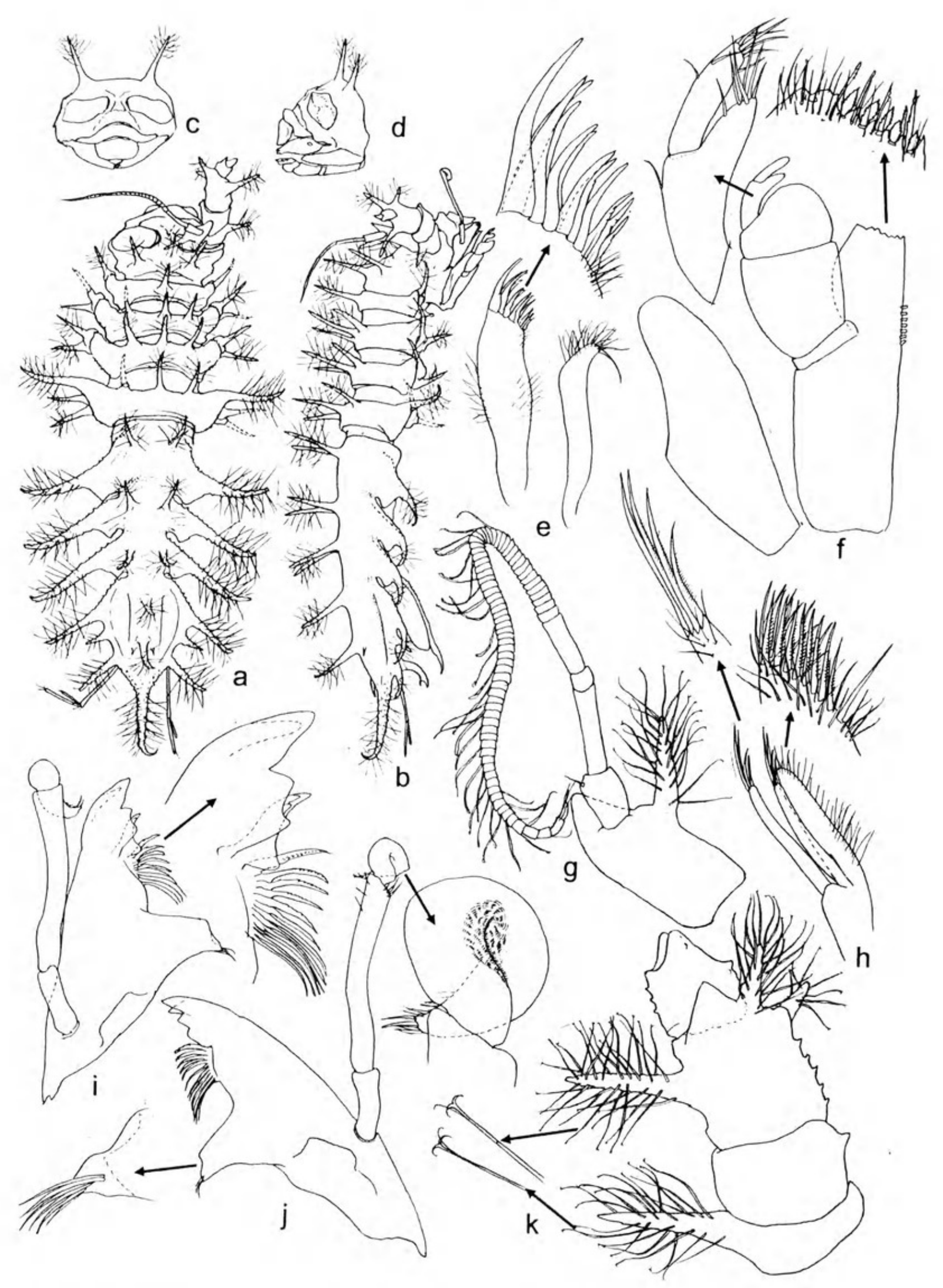

Figure 1. Storthyngurella hirsuta sp. nov., male, holotype: a, b, dorsal and lateral views of body; c, d, frontal and lateral views of cephalon; e, maxilla $1 ; \mathrm{f}$, maxilliped; $\mathrm{g}$, antenna $1 ; \mathrm{h}$, maxilla $2 ; \mathrm{i}$, left mandible; $\mathrm{j}$, right mandible; $k$, peduncle of antenna 2. 


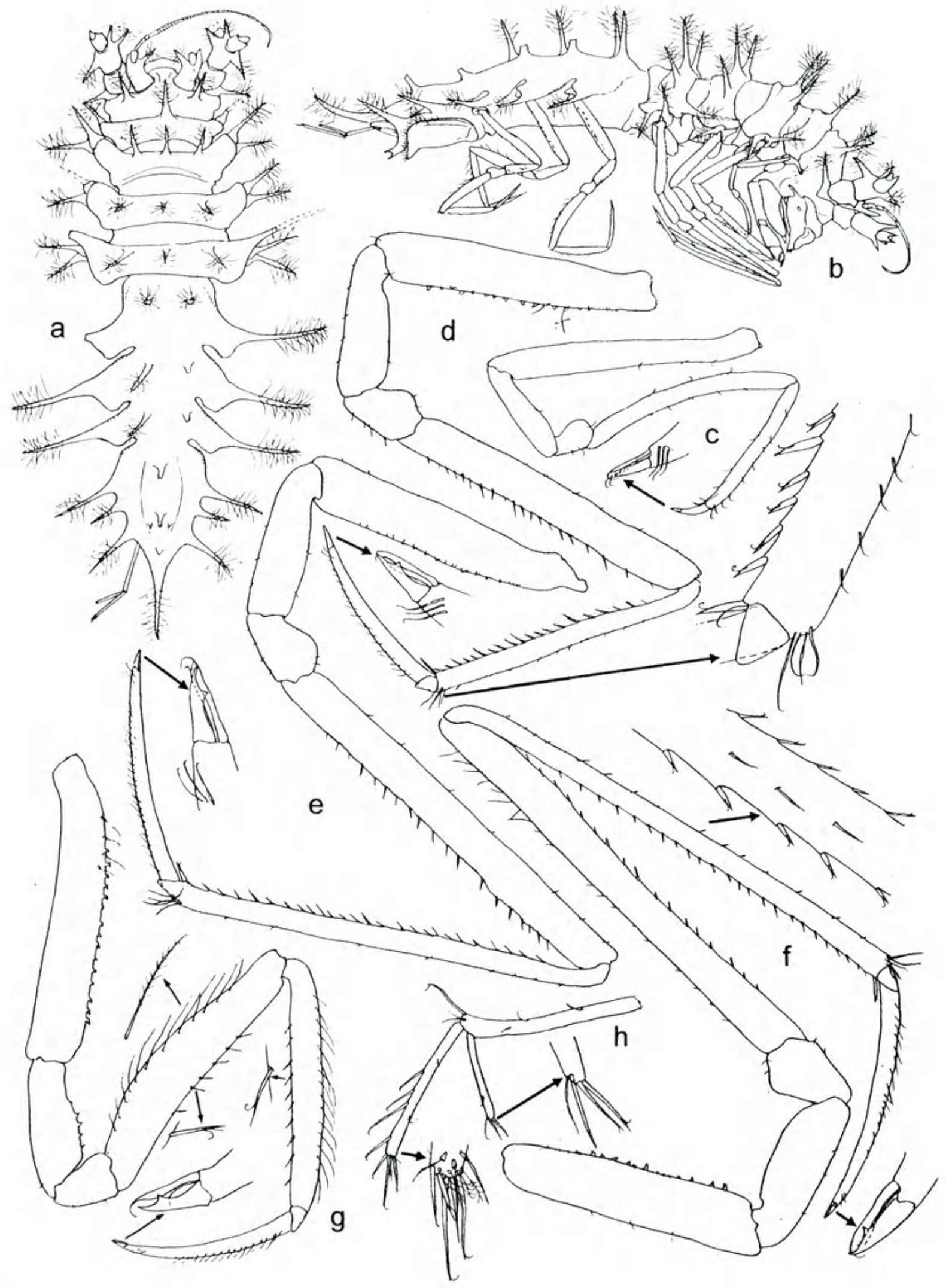

Figure 2. Storthyngurella hirsuta sp. nov.: a, b, female, paratype, dorsal and lateral views of body; male, holotype: $\mathrm{c}-\mathrm{g}$, pereopods $1-5 ; \mathrm{h}$, uropod. 


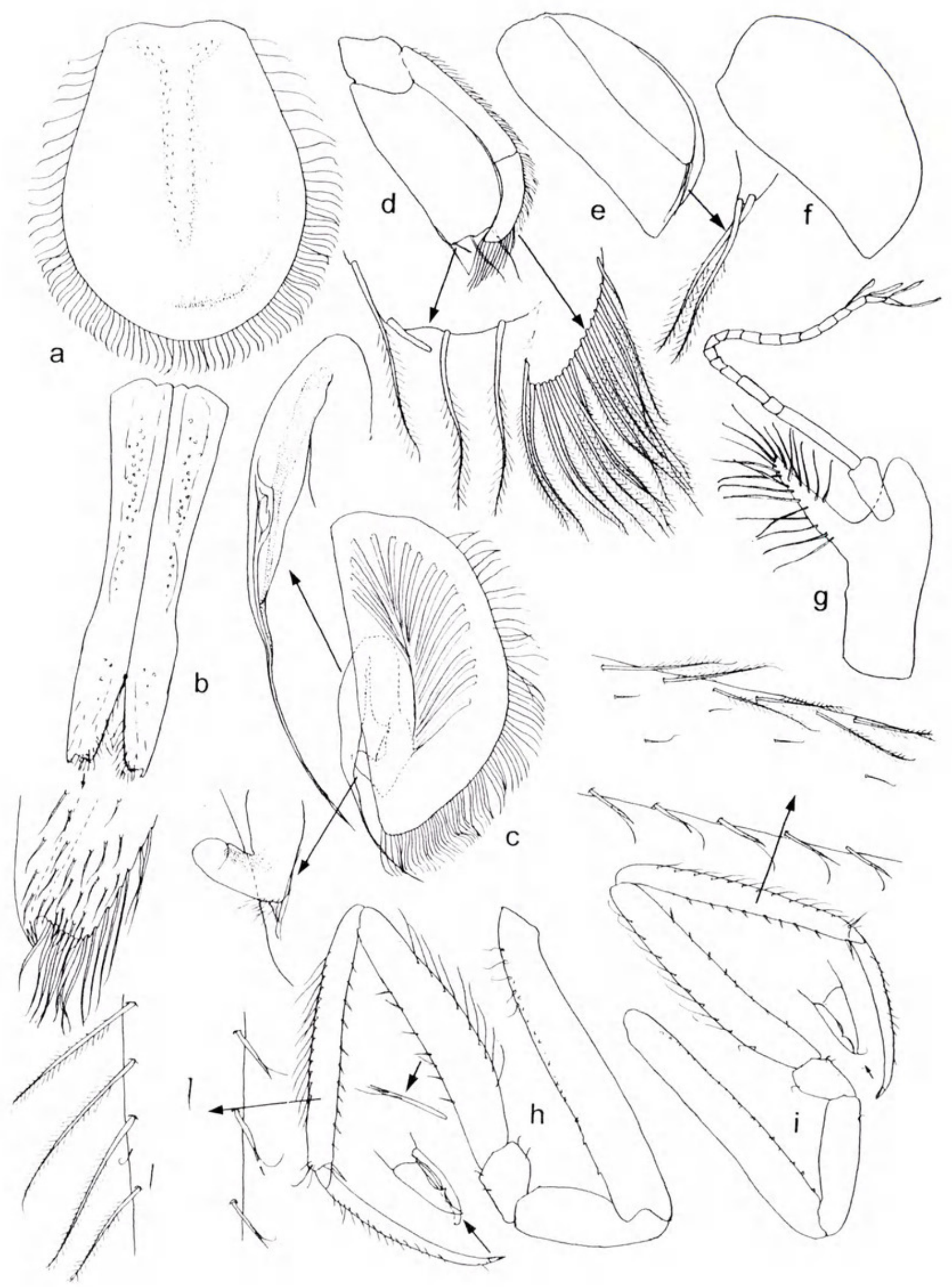

Figure 3. Storthyngurella hirsuta sp. nov.: a, operculum of female, paratype; b-f, pleopods 1-5 of male, holotype; $\mathrm{g}$, antenna 1 of female, paratype; h, i, pereopods 6,7 of male, holotype. 
Description of the holotype. Body (Figs 1a, b) slender, length 3.4 times width, height 0.14 times length. Cephalon length 0.56 times width, distance between antennae 1 is 0.1 cephalon width. Frons (Figs 1c, d) sloping, concave medially, frontal arch low, clypeus 1.9 times as long as labrum, clypeus width 0.8 labrum width. Pereonite 1 with 1 , pereonites $2-4$ with 3 dorsal medial long spines. Anterolateral spines of pereonite 4 perpendicular to body axis, half as long as pereonite width. Coxae spines of pereopods 1-4 much shorter than lateral spines of pereonite 4 . Posterior body part 1.3 times as long as anterior part. Pereonite 5 longer than pereonites 6 and 7 , the last 2 subequal in length, with long waist in anterior part; pereonites gradually narrowing from 5 to 7 , their long anterolateral spines direct backward and slightly upward distally.

Pleotelson subtriangular, its length 1.2 times width, terminal spine length 0.7 pleotelson length, spine turning up distally, its lateral sides with 3 spines: anterior and posterior long, slightly curved upward, medial spine shorter, curved downward. Dorsal surface with 2 long medial spines and 2 short spinules on the sides and slightly behind the posterior medial spine. Preanal ventral process of pleotelson long, narrow, slightly curved backward, with concave notch. Lateral margins of pereonites, pleotelson, and body spines covered with small acute tubercles. All spines on body, coxae and antennae look like bristle-scourer, with dense, long, hair-like bifid setae (Fig. 1k).

Antenna 1 (Fig. 1g) length 0.3 times body length, article 1 is 2.3 times as long as wide, article medial length 1.3 article width, article 1 extends almost to article 2 distal end. Article 2 length 0.45 article 1 length, articles 3-5 length $1.2,0.3$, and 0.9 article 2 length respectively, flagellum of numerous short articles, some with aesthetascs.

Antenna 2 (Fig. 1k) broken, only basal part present. Article 1 lateral spine equal in length to article 1 width, article 2 twice as long as article 1, article 3 almost twice as long as article 2, with long lateral spine and 2 shorter medial spines.

Mandibles (Figs li, j). Incisor process with 4 cusps, lacinia mobilis of left mandible considerably broadening distally, almost half as long as incisor process, with 4 teeth, spine row with 11 and 12 members in left and right mandibles respectively, palp thin. slightly longer than mandibular body, article 2 is 3 times as long as article 1, with few distal setae, article 3 narrow, with numerous setules in inner surface and 5 stout distal setae.
Maxilla 1 (Fig. 1e). Inner lobe half as long as and narrower than outer lobe, the latter with 12 claw-like setae, some serrated.

Maxilliped (Fig. 1f). Basis with 7 coupling hooks, endite with 6 fan-setae and numerous thin setae distally, endite width 0.7 basis width, palp article 2 lateral length 1.4 article width, and the width 1.7 endite width, article 3 length 0.25 article 2 lateral length and 0.9 medial length, article 4 medial lobe and article 5 with 5 simple distal setae each. Epipod rounded distally, its length 2.7 width.

All pereopods (Figs 2c-g, 3i, j) ambulatory, thin, similar, but first thinner and disproportionately smaller then others, their length gradually increase from 2 to 4 and then decrease to 7 . Pereopods 1-4 bases subequal in length, slightly longer in pereopods 5-7. All bases with row of small spines and plumose setae on dorsal margin each. Ischia of pereopod 1 and 5-7 less than half corresponding bases length $(0.40,0.42,0.42$, $0.47)$, in pereopods $2-4$ more than half $(0.54$, $0.56,0.60)$. Ratios of lengths of carpi $1-7$ : bases: $0.80,1.20,1.60,1.82,0.94,0.79,0.84$ respectively; propodi : bases: $0.56,1.05,1.76,1.96$, $0.88,0.82,0.84$; and dactyli : bases: $0.15,0.66$, $0.86,0.96,0.66,0.64,0.62$. Carpi $5-7$ slightly flattened and broaded, in pereopod 7 less so. Ventral margins of carpi and propodi 5-7 with thin, unequally bifid setae, dorsal margins with small plumose setae. Dactyli 2-7 with numerous thin, simple dorsal setae.

Pleopod 1 (Fig. 3b) slightly tapering, its length 3.2 proximal width, midlength slightly narrowed, ventral surface lacking setae, but with small tubercules, distal lobes long, $30^{\circ}$ to each other at distance 0.2 of protopod length from distal tip. Inner lobes of distal margin subrectangular with numerous thin long setae, outer lobes narrow, produced, slightly curved inward.

Pleopod 2 (Fig. 3c) length twice width, with dense row of plumose setae, endopod inserted at distance 0.6 of protopod length from basal margin, stylet 0,8 protopod length, well tapering distally, extending not far beyond distal margin of protopod, exopod extrinsic musculature occupying central part of protopod.

Pleopod 3 (Fig. 3d) length 0.8 pleopod 2 length, endopod subrectangular with 4 distal plumose setae, length twice width, exopod narrow, 2 -segmented, longer than endopod, with 16 distal plumose setae and row of thin simple lateral setae.

Pleopod 4 (Fig. 3e). Endopod semicircular with acute distomedial tip, exopod length 0.8 endopod length and 0.5 endopod width, with 2 distal plumose setae. 
Uropod (Fig. 2h) 0.82 pleotelson length. Protopod slightly broadening distally, with 1 long and 2 short distal setae, length 7.8 width. Endopod about half width of protopod and 0.8 protopod length, with 4 medial, 4 lateral strong unequal bifid setae and 5 plumose distal setae.

Female paratype. In appearance and structural details, the female is similar to the male. Antenna 1 (Fig. $3 \mathrm{~g}$ ) shorter than in male, with articles 2-5 thinner, flagellum of about 10 elongated articles. Pereonite 7 with ventromedial stout spine. Operculum (Fig. 3a) oval, length 1.3 width. Keel rounded ventrally, covered with small acute tubercules, distal part elevated and folded, lateral and distal margins with plumose setae.

Etymology. Hirsuta (Latin), hairy or shaggy, referring to the long, dense hairs on the body spines.

Remarks. The new species is most similar to $S$. zenkevitchi. The two species share the same number and arrangement of dorsal spines on pereonites, male pleopod 2 tapering distally, and 4 distal setae on the endopod of the pleopod 3 (all other species have 3 setae). The new species is distingished by longer body spines, longer terminal spine on the pleotelson, different length of the lateral spines of pleotelson and in having long, dense hairs on the body spines.

\section{Storthyngurella wolffi sp. nov.}

\section{Figures $4-6$}

Material examined. Holotype. RV Dmitrii Mendeleev, cruise 16, stn $1349\left(46^{\circ} 36.5^{\prime} \mathrm{S}, 144^{\circ} 04^{\prime} \mathrm{E}\right), 4464 \mathrm{~m}$, ZMMU Mc 1318 (male, $9.1 \mathrm{~mm}$ long).

Paratypes. Type locality, ZMMU Mc 1319a (4 females, 6.8-10.7 mm long), NMV J45732 (1 male, 1 female). Stn 1285 ( $\left.54^{\circ} 57.5^{\prime} \mathrm{S}, 163^{\circ} 51.3^{\prime} \mathrm{E}\right), 4590-4560$ m, ZMMU Mc 1319b (1 male, 11 mm long) Stn 1299 $\left(57^{\circ} 17^{\prime} \mathrm{S}, 157^{\circ} 13^{\circ} \mathrm{E}\right), 5760-5460 \mathrm{~m}, \mathrm{ZMMU}$ Mc $1319 \mathrm{c}$ (1 male, $12.3 \mathrm{~mm}$ long).

Description of holotype. Body (Figs 4a, b) length 3.2 times width, height 0.2 times length. Cephalon (Figs $4 \mathrm{c}$, d) length 0.5 width, distance between antennae 10.12 cephalon width, frons concave medially, frontal arch low, clypeus twice as broad and half as long as labrum. Pereonites $1-4$ with 1 dorsal medial long spine each. Anterolateral spines of pereonite 4 perpendicular to body axis, equal in length to pereonite medial length. Coxal spines of pereopods 1-4 almost twice as long as anterolateral spines of pereonite 4 . Natasome 1.3 times as long as anterior body part. Pereonite 5 slightly longer than pereonites 6 and 7 , the last 2 subequal in length, pereonites gradually narrowing from 5 to 7 , their long anterolateral spines directed slightly forward. Pereonites ventral side with small acute medial spines.

Pleotelson pentagonal, separated by clearly visible suture, length 1.1 width, terminal spine almost straight, length 0.6 pleotelson length, lateral sides bearing 2 long spines subequal in length to terminal spine, and rectangular projection between them directed slightly down. Dorsal surface with 2 long medial spines and 2 short on sides and slightly behind posterior medial spines. Preanal ventral process of pleotelson long and broad, turned backwards, visible in dorsal view, with deep serrated medial notch and long lateral spines almost reaching tip of terminal spine. Lateral margins of pereonites with fine denticles, margins of pleotelson and body spines with prominent ones.

Antenna 1 (Fig. 6a) length 0.4 body length, article 1 elongated, 2.3 times as long as wide, article medial spine subequal in length to article, lateral lobe subequal in length to article 2 . Article 2 length 0.3 article 1 length, with distal denticles, articles 3-5 length $1.6,0.3$, and 1.1 of article 2 length respectively, flagellum with many short articles, some with aesthetascs.

Antenna 2 (Fig. 4a) almost twice as long as body. Basal articles 1-3 gradually lengthening, article 1 with long lateral spine almost twice as long as article width, article 2 twice as long as article 1, article 3 about 1.5 as long as article 2, with 1 lateral and 1 medial spines, article 4 shorter than article 3 , length 0.6 width, article 5 twice as long as all preceding articles, article 6 slightly narrower and 1.2 times as long as article 5 . Flagellum with approximately 110 elongated articles.

Mandibles (Figs 4e-g). Incisor process of left mandible broad and very thin, so curved that in frontal view looks narrow, with 4 cusps, lacinia mobilis broadening distally, almost half as long as incisor process, with 4 narrow dorsal and 1 broad ventral tooth, spine row with 13 and 14 members in left and in right mandibles respectively, molar process with 6 denticulated distal setae, palp thin, slightly shorter than mandibular body, first 2 articles equal in width, article 2 is 2.7 times as long as article 1, with 4 distomedial setae, article 3 with 7 large distal setae.

Maxilla 1 (Fig. 4i). Inner lobe width 0.6 outer lobe width, with 12 claw-like setae, some serrated.

Maxilliped (Fig. 4h). Basis with 7 coupling hooks, endite with 6-7 fan-setae and numerous thin setae distally, endite width 0.7 basis width, 


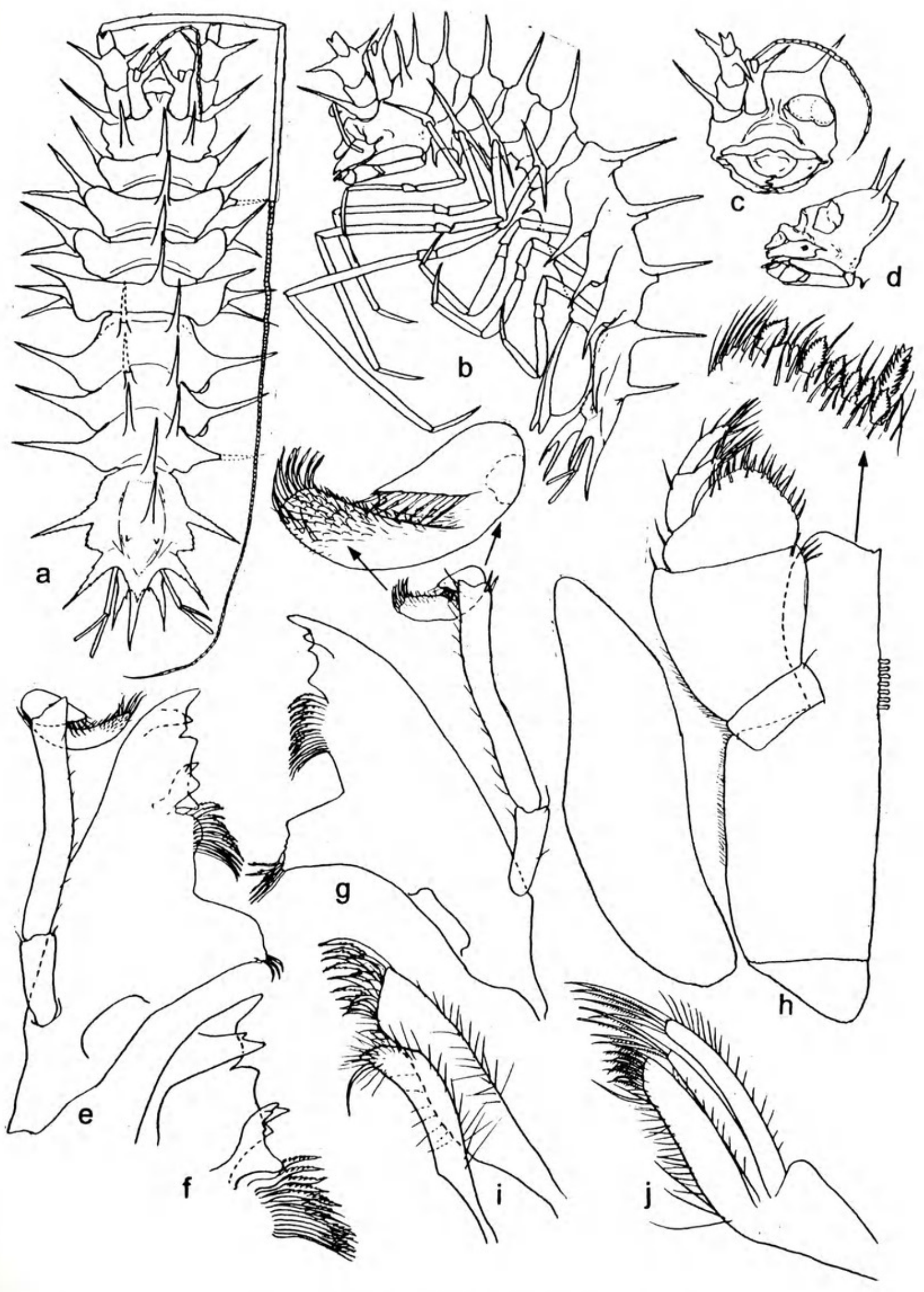

Figure 4. Storthyngurella wolffi sp. nov., male, holotype: a, b, dorsal and lateral views of body; c, d, frontal and lateral views of cephalon; e, left mandible; $\mathrm{f}$, distal part of left mandible; g, right mandible; h, maxilliped; $\mathrm{i}$, maxilla $1 ; \mathrm{j}$, maxilla 2 . 


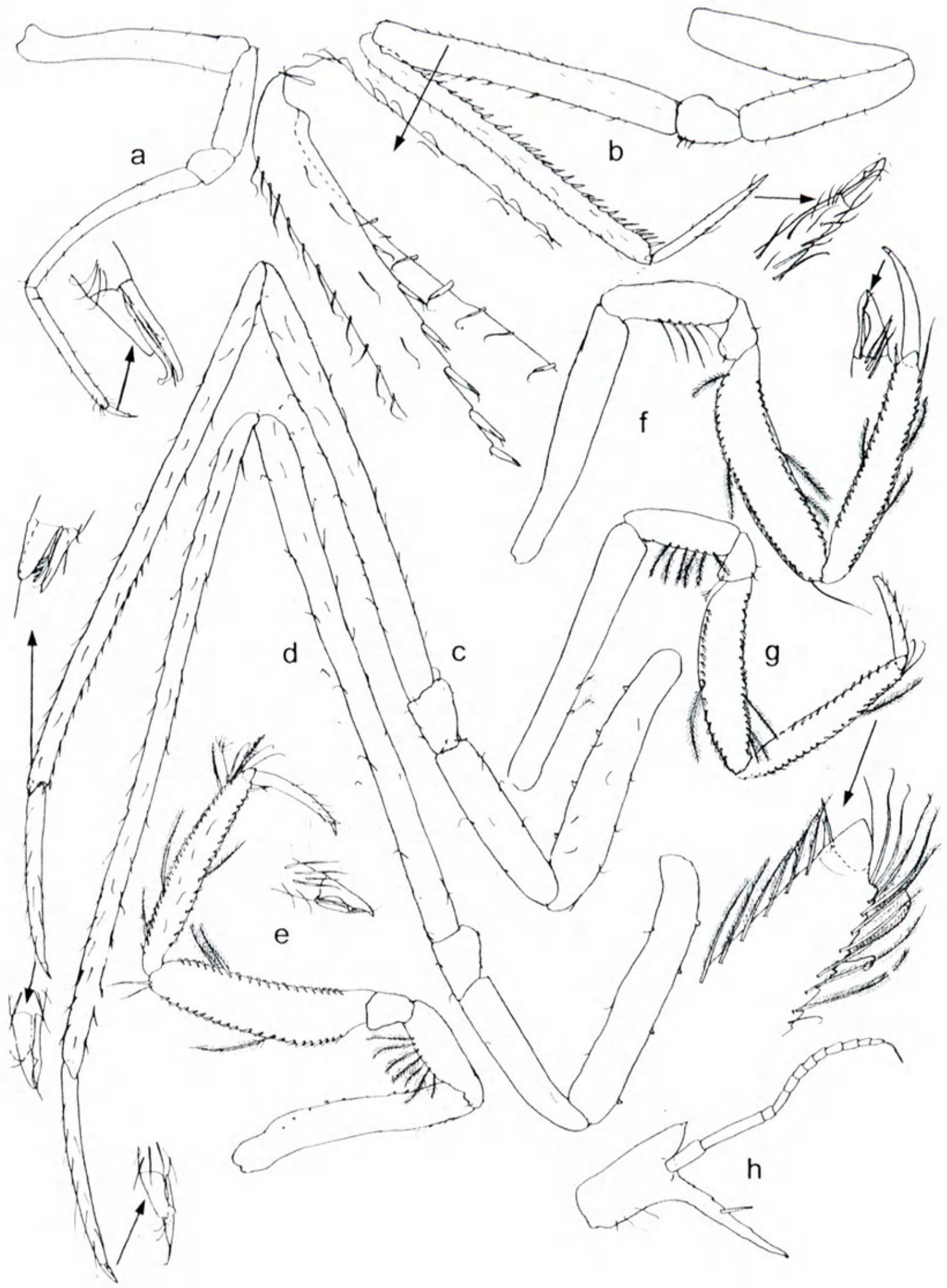

Figure 5. Storthyngurella wolffi sp. nov., male, holotype: a-g, pereopods $1-7 ; \mathrm{h}$, antenna 1 of female, paratype. 


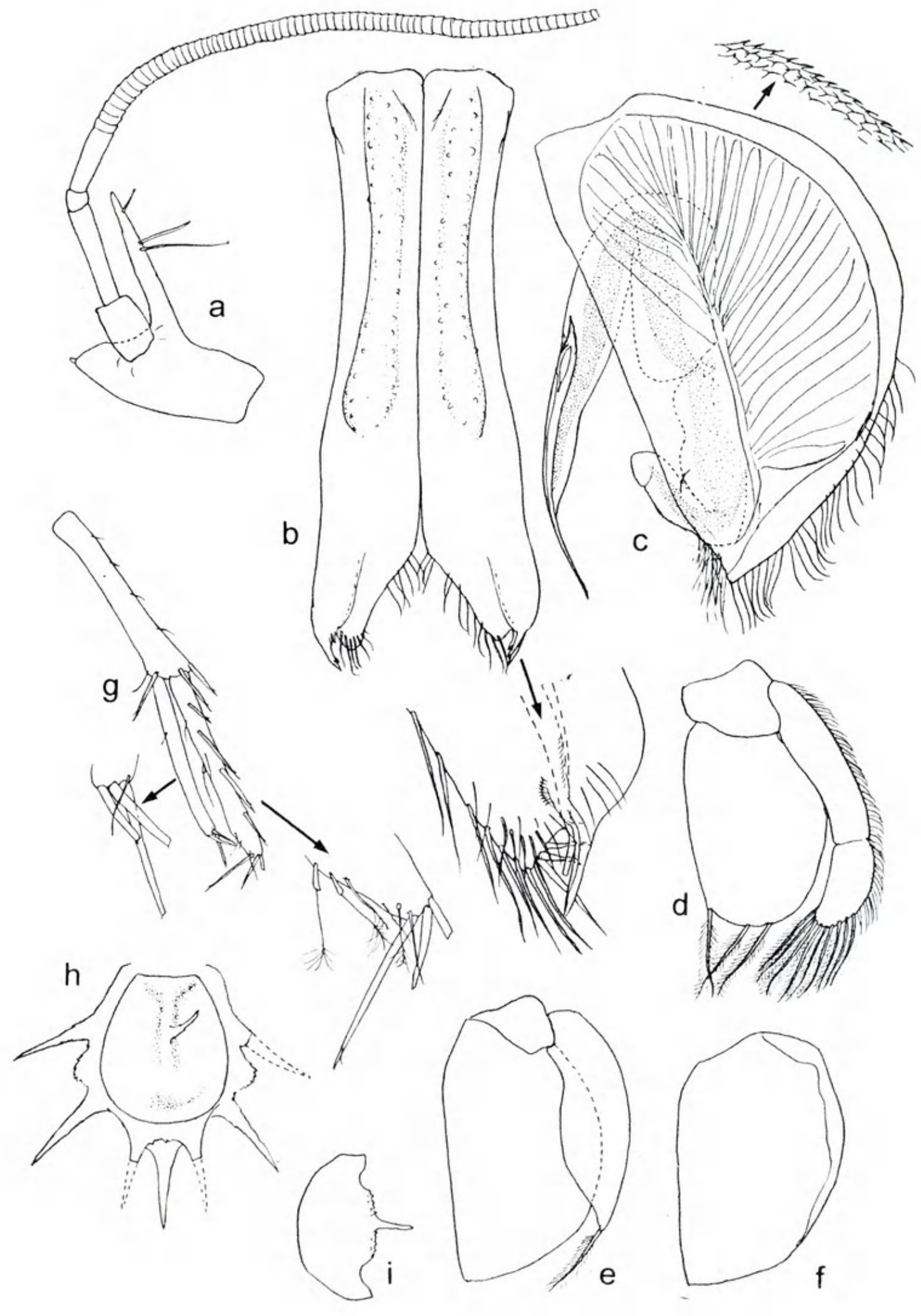

Figure 6. Storthyngurella wolffi sp. nov., male, holotype: a, antenna 1, b-f, pleopods 1-5; g, uropod; female, paratype: $h$, pleotelson, ventral view; i, operculum, lateral view. 
lateral lenght of palp article 2 subequal to article width, and its width 1.7 endite width, article 3 length 0.24 article 2 lateral length and 0.8 medial lenglh, article 4 medial lobe and article 5 with 7 simple distal setac each. Epipod rounded distally, 3 limes as long as wide, lateral margin with smoothed midlengh projection.

Pcrcopods I 4 (Figs 5 a d) ambulatory, thin. similar in structure, first slightly smaller than second, pereopods 3 and 4 much longer than all other, pereopods 57 (Figs $5 e-g$ ) subequal in size and shape. All pereopod bases subequal in size, in pereopods I 4 they are broadest articles. All bascs with small and sparse setac only. Ischia of percopods I and 57 about half of corresponding bases lenghth $(0.46,0.48,0.51,0.42)$, and more than hall in percopods $24(0.79,0.66,0.66)$. Ratios of lenglhs of earpi I 7 : bases: $0.86,1.34$, 1.61, 1.95, 0,94,0,90,0,67 respeclively; propodi : bases: $0.63,1.57,2.04,2.42,0.97,0,95,0.72$; and dactyli bases: $0.1,0,6,0.91,(0.79,0.41,0.4,0.32$ ('arpi 57 flatlened and slightly broadened, lenglh about 4 limes widih, propodi 5.7 lenghl $7.1,6.5$, 6.4 width respectively, both margins of carpi and propodi 57 and dorsal margin of ischia 5-7 with thin short plumose setac. Dactyli $2-7$ with numerous thin, simple dorsal setac

Pleopod I (Fig. ob) relatively broad, broadening distally, lenght 2.7 proximal width, ventral surface lacking setac, but with small high tubercules, distal lobes $70^{\circ}$ to each other at distance (0.2 of pleopod length from distal lip. Inner lobes of distal margin subrectangular wilh numerous thin, long setac, outer lobes narrow, projecting, slightly curved inward.

Pleopod 2 (Fig. 6e) length 1.6 width, endopod inserted 0.6 protopod length from basal margin, stylct 0.9 protopod lenght, strongly tapering distally, not extending beyond distal margin of prolopod, exopod extrinsic musculature oceupying bulk of protopod, coming close to lateral margin. Pleopods I and 2 much larger and thicker than remainder

Pleopod 3 (Fig. 6d) lenght 0.6 pleopod 2 length, endopod subrectangular, lenglh 1.4 width, with 3 distal plumose setac, exopod narrow, slightly longer than endopod, with 9 distal plumose setac and row of thin simple lateral setae.

Pleopod 4 (lig. 6c). Indopod semicircular with aculc distomedial tip, exopod length 0.8 codopod lenght and 0.5 colopod widih, wilh I distal seta.

Uropod (Fig. 6g) 0.86 pleotelson length, extending beyond terminal spine of pleotelson. Protopod slightly broadening distally, with 4 medial setac, length 4.3 widih. Indopod about half width of protopod and slightly shorter $(0.97)$, with 4 medial, 4 distal unequal bifid setae, and I plumose lateral seta, exopod slightly narrower than endopod, its length 0.8 endopod length, with 3 distal unequal bifid setae.

Female paratype. In appearance and structural details, the female is similar to the male. Antenna I (Fig, 5h) almost half as long as in male, article I length 2.2 width, medial spine subequal in length to article, articles $2-5$ length ratio almost same as in male, article 2 subequal in width to following articles, flagellum with 8 elongated articles. Operculum (Figs 6h, i) oval, length 1.3 width. Keel rounded ventrally, covered with small acule tubercules with long, stout spine in midlength, lateral and distal margins with plumose setac.

Exmology. The species is named after the outstanding Danish carcinologist, Prof. Torben Wolli.

Remarks. The specimens varied little. Lateral spines of the preanal process are broken in all specimens except the holotype. The new species is identified as Storthyngurella by the combination of the following features: long spines on the body, coxac I 4, and basal articles of both antennac; long terminal spinc and preanal process on the pleotelson narrow carpi and propodi of percopods 5 7; shape of male pleopods 1 and 2; armament of pleopods 3 ; and long uropods. But $S$. wolffi is distinguished from the other species of the genus by unusual shape of pleotelson and 1 (not 3) dorsal spine on pereonites 2-4. The only other species with I dorsal spine on pereonites 24 is $S$. henti, but pleotelson shape in this species is common for the genus. The presence of two lateral spines on pleotelson makes $S$. wolffi similar only to $S$ digitata, but spines on the pleotelson and pereonites of the latter species are different.

\section{Storthyngurella menziesi sp. nov.}

Figures 7,8

Material examined. Holotype. Argentine Basin, RV Dmitrii Mendeleev, cruise 43, sin $4109 \quad\left(38^{\circ} 40^{\prime} \mathrm{S}\right.$, $48^{\circ} 08^{\prime} \mathrm{W}$ ), $5225 \mathrm{~m}$, ZMMU Me 1320 (male, $10.2 \mathrm{~mm}$ long).

Paratypes. Type locality, ZMMU Mc 132 la (2 males, 9,2 , and $9.4 \mathrm{~mm}$; I female, $11.2 \mathrm{~mm}$; fragments of 6 specimens), NMV 145734 (I male, I female). RV Akademik Nurchatos: cruise I1, stn 858 (48.52'S, $26^{\circ} 34 \mathrm{~W}$ ), $45604570 \mathrm{~m}, 7 \mathrm{MMU}$ Mc $132 \mathrm{lb}$ (I female, $14.3 \mathrm{~mm}$ long)

Description of the holotype. Body (Figs 7a, b) length 3.2 times width, height 0.15 times length. 


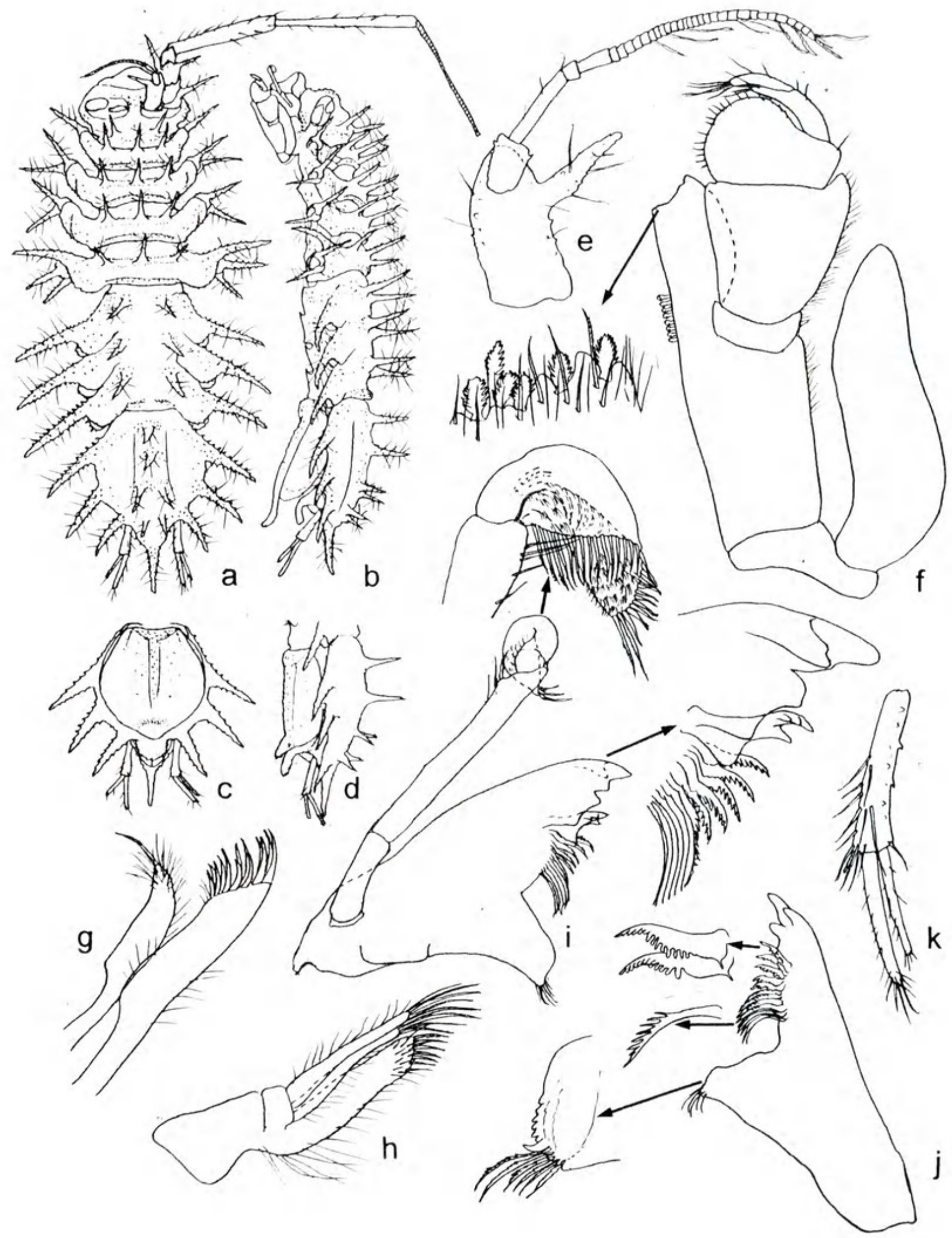

Figure 7. Storthyngurella menziesi sp. nov. a, b, f-k, male, holotype; c-e, female, paratype. a, b, dorsal and lateral views of body; c, d, pleotelson, ventral and lateral views; e, antenna 1; f, maxilliped; g, maxilla 1; h, maxilla 2; i, left mandible; j, right mandible; k, uropod. 


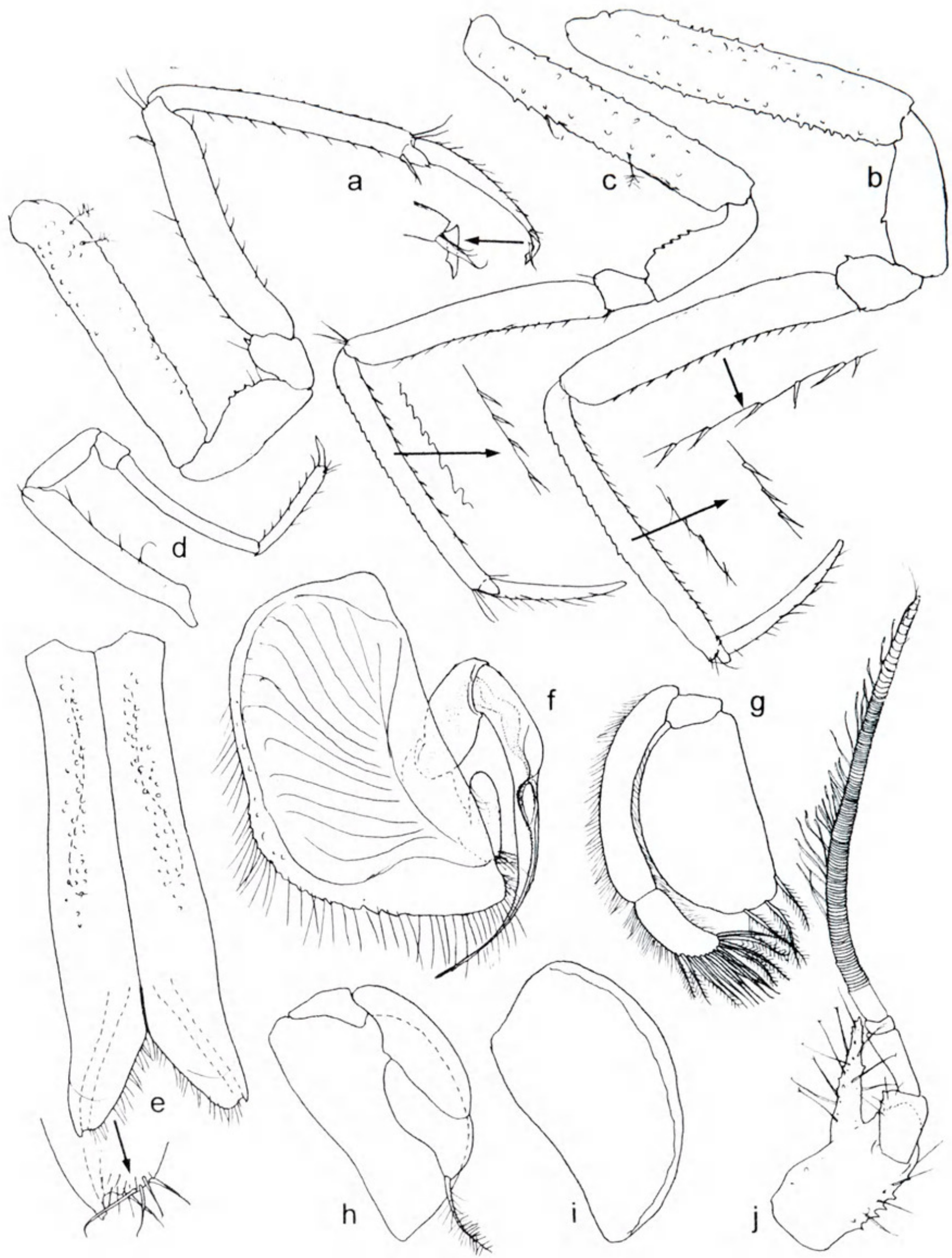

Figure 8. Storthyngurella menziesi sp. nov., male, holotype: a-c, pereopods 5-7; d, pereopod 1; e-i, pleopods 1-5; j, antenna 1 . 
Cephalon length 0.5 width, distance between antennae 1 is 0.15 cephalon width, antennal sockets well marked, frons slightly concave medially, clypeus 1.75 times as broad and half as long as labrum. Pereonite 1-4 with 3 dorsal long spines. Anterolateral spines of pereonite 4 perpendicular to body axis, equal in length to half of pereonite width. Coxal spines of pereopods 1-4 shorter than anterolateral spines of pereonite 4 . Natasome 1.3 times as long as anterior body part. Pereonites 5-7 subequal in size, their anterolateral spines long, directed slightly backward.

Pleotelson triangular, length 1.1 width, terminal spine straight, length 0.35 pleotelson length, lateral sides with 3 long subequal spines directed backward, parallel to lateral spines of pereonites 5-7. Anterior part of pleotelson with 2 long dorsal medial spines, posterior part with 2 pairs of shorter spines. Preanal ventral process of pleotelson broad, semicircular, turned backwards, in ventral view almost completely covering anal operculum. Body surface covered by small acute tubercules, all spines on body, coxae and antennae with long hair-like setae.

Antenna 1 (Fig. 8j) length 0.25 body length, article 1 elongate, 2.2 times as long as wide, article medial spine 1.6 times as long as article width, lateral lobe extends almost to distal tip of article 2. Article 2 with 2 distal setae, length 0.4 article 1 length, article 3-5 lengths 1.1, 0.3, 0.9 article 2 length respectively, flagellum with numerous short articles, some with aesthetascs.

Antenna 2 (Fig 7a). Basal articles 1-3 gradually lengthening, long lateral spine of article 1 subequal in length to coxal spines of pereopods $1-4$, article 2 distinctly longer than article 1 , article 3 subequal in length to article 2 , with 1 lateral and 1 medial spines, article 4 half as long as article 3 , length 0.6 width, article 5 twice as long as total length of all preceding articles, article 6 slightly narrower and 1.4 times as long as article 5. Flagellum with elongate articles, most broken off.

Mandibles (Figs 7I, j). Incisor process of both mandibles with 4 cusps, lacinia mobilis broadening distally, almost half as long as incisor process, with 5 teeth, spine row with 12 and 13 members in left and right mandibles respectively, molar process tip denticulated, with 6 setulose distal setae, palp 1.2 times as long as mandibular body, first 2 articles equal in width, article 2 twice as long as article 1, with 4 distomedial setac, article 3 with setae row on medial margin.

Maxilla 1 (Fig. $7 \mathrm{~g}$ ). Inner lobe width 0.7 outer lobe width, with 13 claw-like setae, some serrated.
Maxilliped (Fig. 7f). Basis with 8 coupling hooks, endite with 6 fan-setae distally, endite width 0.6 basis width, lateral length of palp article 2 almost equal to article width, its width twice endite width, article 3 length 0.3 article 2 lateral length and 0.7 medial length, medial margin with 17-18 stout setae, article 4 medial lobe and article 5 with 5 simple distal setae each. Epipod rounded distally, lateral margin semicircular, length 2.3 width.

Pereopods 2-4 broken, only bases present. Pereopods $1-4$ bases subequal in length, those of pereopods 5-7 slightly longer, all bases with row of small spines and plumose setae on dorsal margin. Pereopod 1 (Fig. 8d) almost half as long as pereopods 5-7, pereopods 5-7 (Fig. 8a-c) subequal in size and shape, with tubular articles, pereopod 6 longest. Ischia of pereopods 1 and 5-7 about half corresponding basis length $(0.43,0.50$, $0.48,0.41$ ). Ratio of lengths (pereopods 1 and 5-7) carpi : bases: $0.76,0.87,0.84,0.81$ respectively; propodi : bases: $0.48,0.87,0.90,0.86$; and dactyli : bases: $0.15,0.56,0.51,0.47$. Carpi 5-7 slightly and propodi half as wide as bases. Ventral margins of carpi and propodi 5-7 with thin, short unequal bifid setae, dorsal margins denticulated, with thin short simple setae. Dactyli with numerous thin simple dorsal setae.

Pleopod 1 (Fig. 8e) relatively broad, broadening distally, length 2.8 distal width, ventral surface lacking setae, but with small high tubercules, distal lobes $70^{\circ}$ to each other at distance 0.2 protopod length from distal tip. Inner lobes of distal margins semicircular, with numerous thin long setae, outer lobes narrow, expanded, slightly curved inward.

Pleopod 2 (Fig. 8f) length 1.7 width, endopod insert in midlength of protopod medial margin, stylet subequal in length to protopod, strongly tapering distally, extending beyond distal margin of protopod, exopod extrinsic musculature extending almost throughout protopod. Pleopods 1 and 2 much larger and thicker than remaining ones.

Pleopod 3 (Fig. 8g) length 0.6 pleopod 2 length, endopod subrectangular, length 1.4 width, with 3 distal plumose setae, exopod narrow, width 0.3 endopod width, 1.6 times as long as endopod, with 9 distal plumose setae and row of thin simple marginal setae.

Pleopod 4 (Fig. 8h). Endopod semicircular, exopod 2-articulated, length 0.8 endopod length and width 0.6 endopod width, with 1 distal setae.

Uropod (Fig. 7k) 0.46 pleotelson length, extending slightly beyond terminal spine of pleotelson. Protopod slightly broadening distally, with 
8 medial and 6 distal setae, length 4.2 width. Endopod 0.4 width of protopod and slightly shorter (0.97), with row of small medial and 6-7 distal unequal bifid setae, exopod slightly narrower than endopod, its length 0.8 endopod length, with 3 distal unequal bifid setae.

Female paratype. In appearance and structural pattern, the female is similar to the male. Antenna 1 (Fig. 7e) about 1.5 times shorter than in male, article 1 length 2.1 width, medial spine length 0.65 article length, articles $2-5$ length ratio similar to that of male, flagellum with about 30 elongate articles. Operculum (Figs 7c, d) oval, length 1.1 width. Keel rounded ventrally, covered with small acute tubercules, distal part turned upward.

Etymology. The species is named after the late outstanding American carcinologist Dr Robert Menzies who described, among others, many species of the genus Storthyngura.

Remarks. The new species is most similar to $S$. triplispinos $a$ by body shape, number and arrangement of body spines, and tubular last three pairs of legs lacking natatory setae. The major difference between the species is the number of dorsal spines on the pleotelson: six in the new species and four in $S$. triplispinosa. S. menziesi is also distinguished by more slender body (body length is 3.2 times body width in the new species and 2.8 times in S. triplispinosa); and a longer exopod of uropod (endopod to exopod length ratio is 1.21 in the new species and 1.64 in S. triplispinosa). Both $S$. benti and $S$. zenkevitchi have a similar shaped pleotelson with three lateral spines and a relatively short terminal spine but these species have different numbers and arrangements of dorsal spines on the pleotelson: $S$. benti has two medial spines and a pair of tubercules on both sides of posterior spine, and $S$. zenkevitchi has one dorsal medial spine on the anterior part of the pleotelson and three tubercules in posterior part.

\section{Storthyngurella triplispinosa (Menzies, 1962) comb. nov.}

Figures 9, 10d

Storthyngura triplispinosa Menzies, 1962: 149, fig. 38A-E. - George and Menzies, 1968a: 177. - George and Menzies, 1968b: 298, fig. 12B.

Material examined. Argentine Basin, RV Dmitrii Mendeleev, cruise $43, \operatorname{stn} 4094\left(60^{\circ} 42^{\prime} \mathrm{S}, 41^{\circ} 03^{\prime} \mathrm{W}\right)$, $4670 \mathrm{~m}$ (pleotelson of female); stn $4086\left(60^{\circ} 50^{\prime} \mathrm{S}\right.$, $41^{\circ} 10^{\prime} \mathrm{W}$ ), $6130-6420 \mathrm{~m}$ (female, $6.4 \mathrm{~mm}$ long; fragments of 2 specimens); stn $4090\left(60^{\circ} 52^{\prime} \mathrm{S}, 40^{\circ} 56^{\prime} \mathrm{W}\right)$, 6145-5550 m (fragments of 2 specimens); RV Akademik Kurchatov, cruise 11, stn $914\left(56^{\circ} 21^{\prime} \mathrm{S}\right.$, $50^{\circ} 48^{\prime} \mathrm{W}$ ), 5650-6070 $\mathrm{m}$ (anterior part of female with oostegites); cruise $43, \operatorname{stn} 4904\left(32^{\circ} 10^{\prime} \mathrm{S}, 63^{\circ} 05^{\prime} \mathrm{W}\right)$, 3880-3930 m (1 male, $7.5 \mathrm{~mm}$ long).

Remarks. These specimens were identified as S. triplispinosa only on the basis of external similarities with holotype drawings; there was no opportunity to compare my specimens with type material. Besides the dorsal view of an entire specimen, Menzies presented only drawings of some details: antenna 1, pereopod 1, distal part of pleopod 1 and uropod. These details in my specimens are the same. Here I provide drawings of other appendages.

\section{Storthyngurella digitata (Menzies, 1962)} comb. nov.

Figure 10e

Storthyngura digitata Menzies, 1962: 146, figs 37 $\mathrm{F}-\mathrm{C}$.

Material examined. Argentine Basin, RV Dmitrii Mendeleev, cruise 43, stn $4109\left(38^{\circ} 40^{\prime} \mathrm{S}, 48^{\circ} 08^{\prime} \mathrm{W}\right)$, $5225 \mathrm{~m}$ ( 1 female without pleotelson); RV Akademik Kurchatov, cruise 43, stn $4893\left(36^{\circ} 12^{\prime} \mathrm{S}, 49^{\circ} 10^{\prime} \mathrm{W}\right)$, $4630 \mathrm{~m}$ ( 1 female, $6.5 \mathrm{~mm}$; 1 male $6.8 \mathrm{~mm}$ long).

Remarks. Although the body processes of $S$. digitata are neither long nor spine-like, but bulbous, and the pleotelson does not have a long terminal spine, this species is placed in Storthyngurella because of the typical arrangement of processes on the body, the first arcticles of both antennae, narrow carpi and propodi of pereopods $5-7$, the morphology of first pairs of male pleopods, and three distal setae on the endopod of pleopod 3.

\section{Acknowlegements}

The project was undertaken with partial financial support of RFBR (grant N 97-049724).

\section{References}

Beddard, F.E., 1885. Preliminary notice of the Isopoda collected during the voyage of H.M.S. 'Challenger'. - Part II. Munnopsidae. Proceedings of the Zoological Society of London 1885: 916-925.

Birstein, Ya. A., 1969. Crustacea Isopoda from the Romanche Trench. Byulleten' Moskovskogo Obshchestva Ispytatelei Prirody. Otdel Biologicheskii 3: 50-69. [in Russian]

Malyutina, M.V., in press. New information on Acanthocope Beddard, 1885 (Crustacea, Isopoda, Munnopsidae). Russian Journal of Marine Biology.

George, R.Y. and Menzies, R.J., 1968a. Distribution and probable origin of the species in the deep-sea isopod genus Storthyngura. Crustaceana 15: 171-187. 


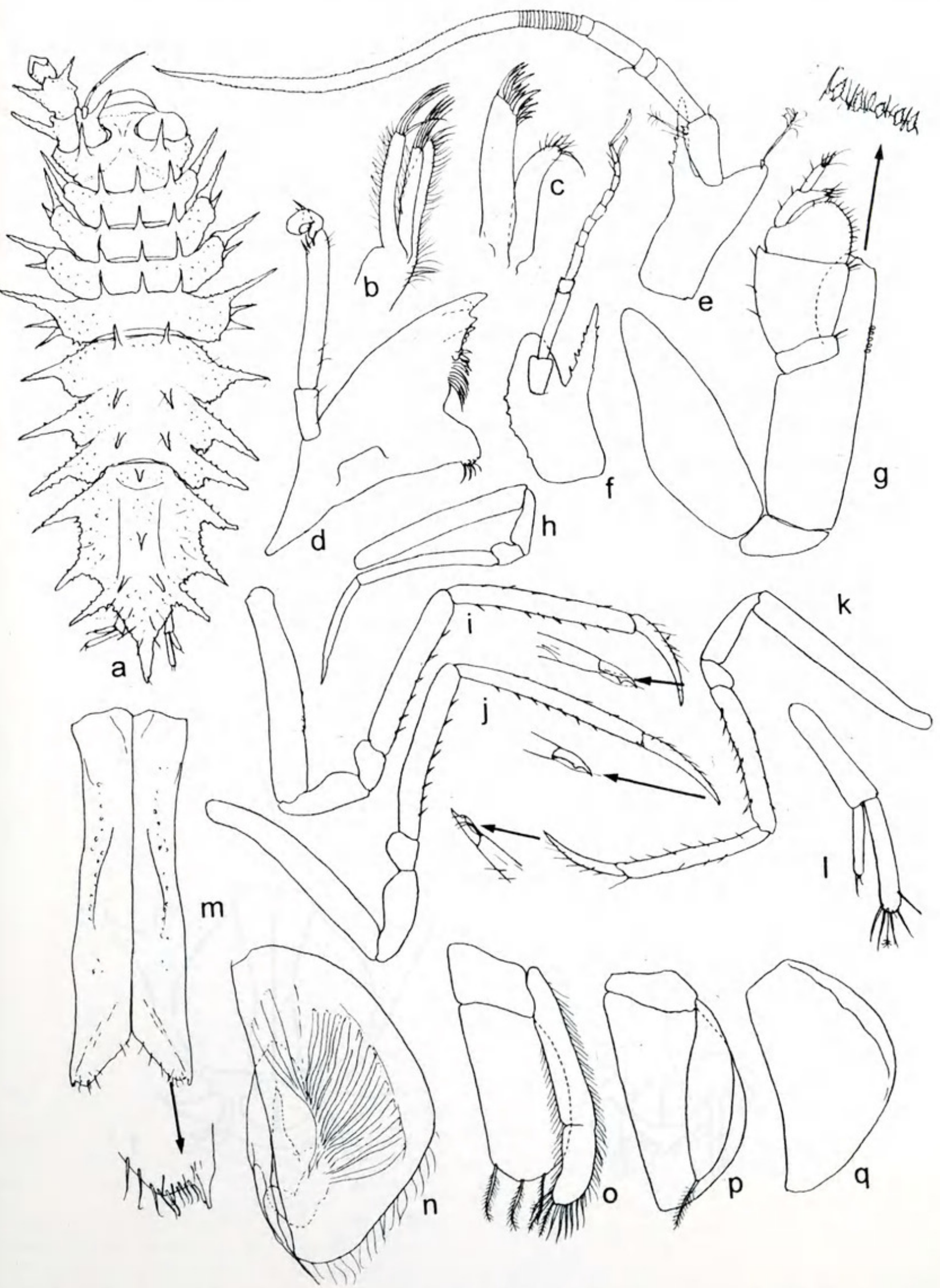

Figure 9. Storthyngurella triplispinosa (Menzies, 1962). All except f, male from stn 4904: a, dorsal view of body; b, maxilla 2; c, maxilla 1; d, left mandible; e, antenna 1; f, antenna 1 of female from stn 4904; $\mathrm{g}$, maxilliped; h, pereopod 1 ; i-k, pereopods 5-7; 1 , uropod; $\mathrm{m}-\mathrm{q}$, pleopods $1-5$. 

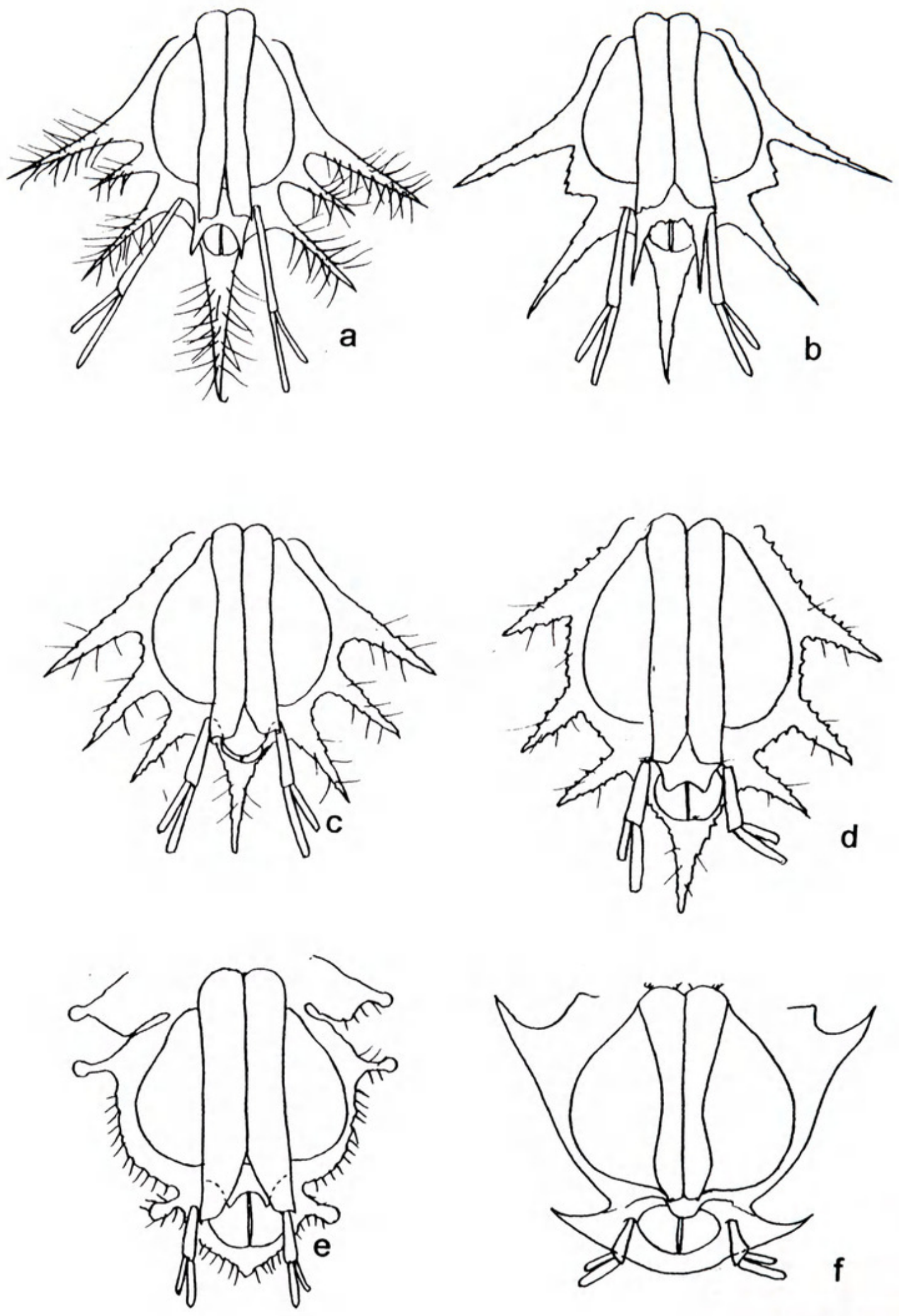

Figure 10. Structure of male operculum in five species of Storthyngurella gen. nov. and one species of Storthyngura: a, Storthyngurella hirsuta sp. nov. ; b, S. wolffi sp. nov.; c, S. menziesi sp. nov.; d, S. triplispinosa (Menzies, 1962); e, S. digitata (Menzies, 1962); f, Storthyngura birsteini Menzies, 1962. 
George, R.Y. and Menzies, R.J., 1968b. Species of Storthyngura (Isopoda) from the Antarctic with descriptions of six new species. Crustaceana 14: 275-301.

Menzies, R.J., 1962. The isopods of abyssal depths in the Atlantic Ocean. Vema Research Series 1: 79-206.

Wägele, J.-W., 1989. Evolution und phylogenetisches System der Isopoda. Stand der Forschung und neue Erkenntnisse. Zoologica (Stuttgart) 140: 1-262.

Wilson, G.D. and Hessler, R.R., 1980. Taxonomic characters in the morphology of the genus Eurycope
(Isopoda, Asellota) with a redescription of Eurycope cornuta G.O. Sars, 1864. Cahiers de Biologie Marine 21: 241-263.

Wilson, G.D., Kussakin, O.G. and Vasina, G.S., 1989. A revision of the genus Microprotus Richardson with descriptions of two new species, M. acutispinatus and M. lobispinatus (Asellota, Isopoda, Crustacea). Proceedings of the Biological Society of Washington 102(2): 339-361.

Wolff, T., 1956. Isopoda from depths exceeding 6000 meters. Galathea Report 2: 85-157. 


\section{$2 \mathrm{BHL}$ Biodiversity Heritage Library}

Malyutina, M V. 1999. "Storthyngurella, new genus of Munnopsidae (Crustacea: Isopoda), with descriptions of three new species from deep-sea basins of the Southern Hemisphere." Memoirs of Museum Victoria 57, 267-285.

View This Item Online: https://www.biodiversitylibrary.org/item/123000

Permalink: https://www.biodiversitylibrary.org/partpdf/50696

\section{Holding Institution}

Museums Victoria

\section{Sponsored by}

Atlas of Living Australia

\section{Copyright \& Reuse}

Copyright Status: In copyright. Digitized with the permission of the rights holder.

Rights Holder: Museums Victoria

License: http://creativecommons.org/licenses/by-nc-sa/4.0/

Rights: https://biodiversitylibrary.org/permissions

This document was created from content at the Biodiversity Heritage Library, the world's largest open access digital library for biodiversity literature and archives. Visit BHL at https://www.biodiversitylibrary.org. 